\title{
Economic Diversification and the Urban Image; Changing the Narrative on Street Vending
}

\author{
PhD Candidate MUHAMMAD K. BALARABE 1 (D), * PhD Candidate ABDULSALAM I. SHEMA 2 (D), \\ M.SC. MARYAM AHMAD 3 \\ 'Department of Architecture, Kaduna State University. Kaduna state, Nigeria. \\ 2Department of Architecture, Cyprus International University. North Cyprus, Turkey. \\ 3Department of Economics, Kaduna State University. Kaduna state, Nigeria.

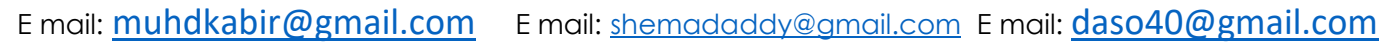

\begin{tabular}{l}
\hline A R T I C L E I N F O: \\
\hline Article history: \\
Received March 2018 \\
Accepted 14 April 2018 \\
Available online 15 June 2018 \\
\hline Keywords: \\
Public Space; \\
Aesthetic Experience; \\
Street Vending; \\
Urban Design; \\
Urban Environment.
\end{tabular}

This work is licensed under a Creative Commons Attribution NonCommercial - NoDerivs 4.0. "CC-BY-NC-ND"

\begin{abstract}
A B S T R A C T
Street vending is a dynamic phenomenon of network of events, socio-economic and cultural factors while remaining a narration of place. At the metropolitan level, the narrative is negatively skewed towards street vending and its aesthetic reality, contemporaneously exploring hostile environmental interventions within the informal sector. This paper attempted to explore a counter-narrative asking; based on aesthetic experience, can the "desired" urban image be achieved by allowing street vendors proliferate in public spaces? This question was asked within the scope of the political-economy of diversification in Nigeria. Mapping over google satellite images over critical periods leading to demolitions and/or developments, this paper documented the spatial distribution of vendors to determine the urban centres that are hostile to vending activities and those that were not. The paper argued that, around public spaces such as parks and sidewalks, the precarious nature of vending activities lead to their diffidence in upgrades to stalls, tables and kiosks. With pictures from spaces that appear to approve of street vending tacitly, a pattern of upgrades in vending apparatus and kiosks were established. This paper proposes an integrative model of passive, active and tacit support that is required to influence the discourse of vending activities within the context of urban images produced in Nigerian. In conclusion and using sing Gouverneur (2014) concepts of receptors and transformers, this paper revealed that potential existing parks within a dense urban area could serve as transformers, creating an urban image that defies that "out of place" narrative associated with vendors.

JOURNAL OF CONTEMPORARY URBAN AFFAIRS (2019) 3(1), 52-61.

https://doi.org/10.25034/ijcua.2018.4682
\end{abstract}

www.ijcua.com

Copyright (c) 2018 Journal Of Contemporary Urban Affairs. All rights reserved.

\section{Introduction}

This paper set out to investigate the following question; can the "desired" urban image be achieved by allowing street vendors proliferate in public spaces? These questions sprung from the competition different actors exact on the urban interface of varying influence. The different dimension to which these forces - such as "developers", "landowners", politicians and administrators and users - shape the

\footnotetext{
* Corresponding Author:

Cyprus International University. North Cyprus, Turkey

E-mail address: shemadaddy@gmail.com
} 
environment is compartmentalized, with each having a strong effect in their particular domain (Alabelewe, A. 2018). On the advice of technical personnel and sometimes towards serving a political goal, politicians/administrators determine the direction of development within the city. Master plans are then produced through a combination of different professionals concerned with the physical, environmental and sociological aspect of the built environment. Urban designers and architects are therefore tasked either by the public or private sectors to come up with schemes that satisfy the initiators' needs and rarely that of the people/users. At the micro level, architects/builders are contracted to make alterations into the physical environment on plots that reflects the wishes, aspirations and personalities of clients. This is the canonised view of how the built environment gains its image, each actor implicated within the verb of creation. However, the repercussions of each action on the final image of a city are incommensurate. The framework of urban development is skewed towards a close network of administrators and professionals, instead of "making [the] process [open] to as wide a group of interests as possible ... [while] identif[ing] who gains and who loses in this process" (Mehar, M. 2012). Power is implicated through the deployment of 'epistemic violence' (Spivak, 1988) in shaping the urban image. The formal process of city building disregards the alternative form of city developmental practices hence subjugating the alternative images produced as a result. It is within this frame of alternatives that street vending lies. Street vending is perceived as producing a distinct urban image when it agglomerates and forms a cluster (Bromley, 2000). To grasp the perceived image produced in such spaces, one needs only to listen to the lexicons used in describing them. Dirty, chaotic, alien, congestion, eyesore are such words that dominate discussions about street vending. It is these dialectic ideas of the city that we ask if they can be resolved within the urban fabric without disparaging the latter. While we do not dispel these characterizations, we argue that it is not an inherent nature of street vending to degenerate the urban landscape, but rather it invests in the physical upgrades of its immediate surrounding. Within the political context of 'diversification' (to be defined in section 2.2), we argue that it provides a unique opportunity for moving away from the misinformed characterizations through inclusivity. In what follows, we map the discussion of urban image shaping and street vending. We then investigate the current situation of street vending in Nigeria's context. The discussion turns to that of political programmes as manifestos and the kind of opportunity they offer in particular to street vending. Finally, our proposals are fitted in the context of 'Receptor' and 'Transformers' to fit into the emerging literature that seeks to offer alternative forms and city building that seeks transform the urban narrative.

\section{Literature Review}

The idea of desiring a distinct urban image to the level of effecting change suggest intense planning with combined power and ability to do so. In contemporary neo-liberal cities, this description is held within a small group of the capitalist, market forces, politicians and designers. As McGlynn and Murrain (1994; 322) have shown, they are the ones who mostly "can initiate and control development in a very direct way [emphasis ours]." The image produced as a result of their (in)actions is one that seeks to perpetuates their political and economic hegemony within the urban environment. Limits to their interventions are bound by their financial power which is planetary (Brenner, 2013; Brenner and Schmid, 2011). This ranges from within the city such as privatizing public spaces through the development of plazas in exchange for increase buildable floor area (Whyte, 1980). It also to new kind of urban development where marginalized areas are integrated through investments and repurposing, often serving as auxiliary points along service points, not for the needs of the local populace.

Dispelling the thought of having a desire for a unified city image, it is worth noting that existing or new enclaves are reshaped and produced to serve a particular end, political or representational. Cities could be identified by their landmarks as an image, though it does not rise to the level of shaping the entire city such as Sydney Opera House conjuring Sydney or as Rockefeller Building might portray New York. However, Shane (2011) has shown that large urban enclaves - China towns or walled citiescan come to represent a city due to their distinct character, with such cities termed 'fragmented metropolis.' These enclaves serve a distinct purpose such as business activities, cultural centres or historical custodians and are often carefully planned and shaped. Such development curates a distinct urban identity (Relph, 1976) by combining distinct functions and social class of people in an area. There are often made to look timely, new and expensive, creating an image that increases social division. 


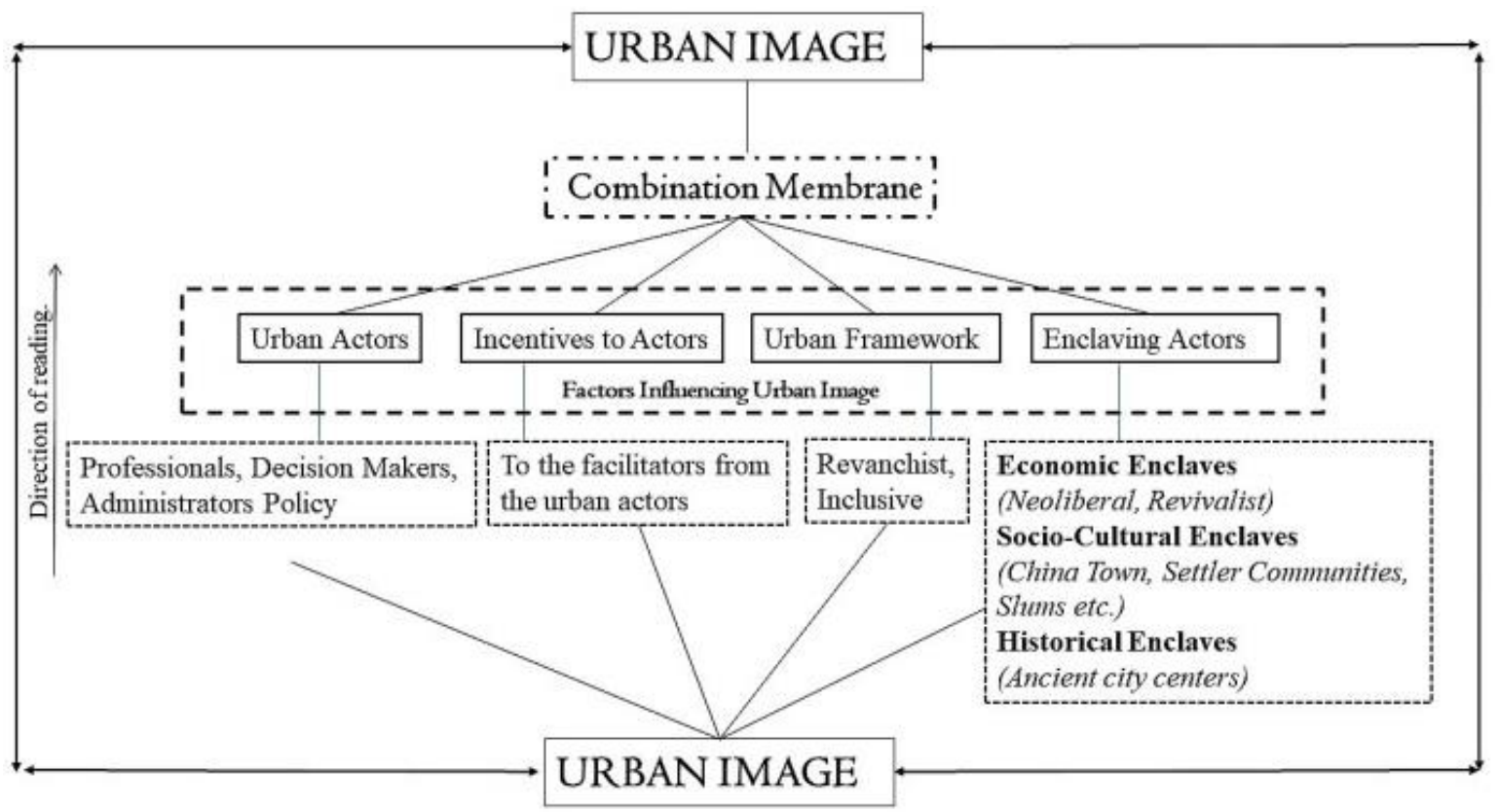

Figure 1. Mapping the theoretical terrain of factors shaping the urban image. The diagram is to be read from bottom up. Any combination of the factors, socio-cultural, economic and historical can coalesce into combination membrane and produce a distinct urban image.Source: Authors, (2018).

Such social divisions are not created arbitrary or randomized within the urban landscape but deliberated targeted where marginalized communities occupy the valuable location. The plans for creating such city images are proposed in these communities. Swanson had argued that these images are created by racism, income inequalities and economic opportunities these atrocities offer. Explaining the case in Ecuador, Swanson posits that the "racial-spatial divide" is a form of urban racism entrenched on an already segregated population by the discourse of urban "cleanliness, hygiene and... aesthetics" (Swanson, 2007; 719).

Such revivalist, regeneration and renewal projects are based on the notion that activities of the street vendors are "out of place" (Yatmo, 2008). The implication is seeing vending and other activities as the 'other' regardless of its contribution to the street life and communities. Crossa (2013) has shown the life generated in Coyoacan's historical Centre from the combination of street artist and vendors, students, cultural activities and intellectuals to be one that a good urban square/plaza should choose to emulate, however, such creative spirit has not stopped the city attempting to clear the centre. However, due to the prevailing language of human rights in urban issues, pro-poor policies and the strength of "deep democracies" (Appadurai, 2001) in organising and creating a voting bloc, there are policies that have begun to cater for the inhabitants of such places with the design and implementation of such projects having varying results (Ortiz, 2011). It is within this recent framework of inclusivity in designing of urban spaces that seeks to eliminate those hostile actions against street vendors that we write our proposal on this paper.

\subsection{Street vending and the Nigerian image experience.}

Street vending in Nigeria has always had a schizophrenic relationship with planners and politicians. On the one hand, street vendors constitute a large voting bloc while still being perceived as a menace to the urban environment. This dichotomous relationship has led to a plethora of policies and government pronunciations. There have been several attempts to reconcile the need for political power, the creation of the clean urban image and street vending activities. Kaduna typifies the nations spirit at this phenomenon. Within four decades, there have been a series of policy shifts. In the 80s under the military regime, allocation "layouts were prepared...for strategically chosen kiosk sites. The design integrated requirements for shopping (through kiosk spaces of approximately $3 \mathrm{~m} \times 4 \mathrm{~m}$ each), circulation and provision for environmental control at these kiosk sites." (Simon, 1998). The drawn plans, however, deal only with already kiosk owners and those who could afford the new spaces, emphasizing what simon characterizes as a tiered informal sector, one 
that neglects those with "micro-enterprises." 2010 ushered in a new master plan policy document for the state. Street trader discussion was minimal and kept to the modern understanding of vendors as negative to the environment.

However, what represented a radical shift was urban design proposal for a bridge crossing over river Kaduna with specific mention to street vending spaces along the two-tier footbridge (Max Lock, 2010). The current administration has taken a different turn to the plight of vendors. In a new Anti-hawking bill, the person who buys or sell is liable to litigation (Binniyat, 2018: Alabelewa, 2016: Sunday et al., 2018). This has created a climate of tension, where vendors are unsure of their traditional-implicit-conditionalapproval.

The anti-hawking bill potency is yet to be established. Vendors are continuously visible at junctions and roadsides. However, there have been some demolitions of illegal shops and stalls around school premises, with viable alternatives yet to be provided. Similar themes occur across different locations across Nigeria. Kano, Lagos Abuja have all exercised state power by demolitions roadside stalls in the name of road expansion, new development and visual nonconformity with the environment (Ahmad, 2015:; COHRE, 2008; Kazeem, 2017).

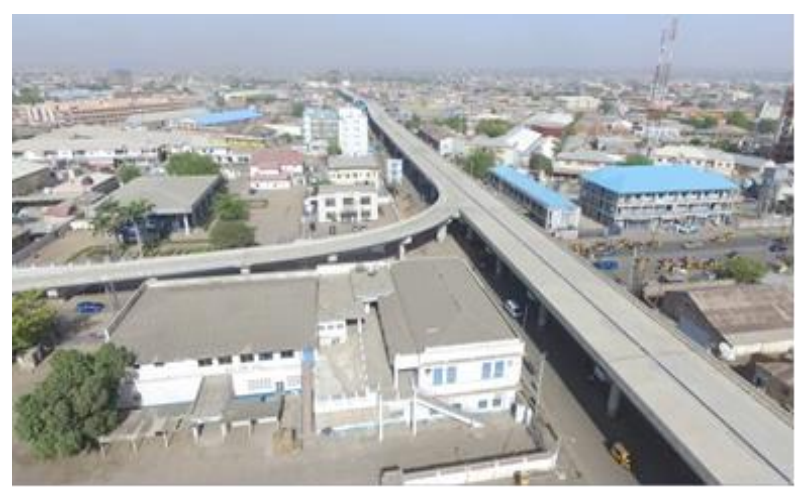

Figure 2: Ariel view of the Murtala Muhammad Way bridge showing a sanitized image that masks the human activity taking place within its vicinity. Source: Salinu T. Yakasai, (2018).

In marginal cases, there have been proposals made by authorities towards street vendors. Mobile phone vendors have been relocated from their precarious grounds in Kano from the post office grounds to a permanent place, albeit less visible at Farm Centre. This has nonetheless proved successful with other vendors congregating around its vicinity, taking advantage of its legal status. However, relegating it to a specialized enclave serves the governments narrative of creating a new and modern environment. These image campaigns are taking place on different platforms, with officials producing sanitized and non-human scale image of the environment.

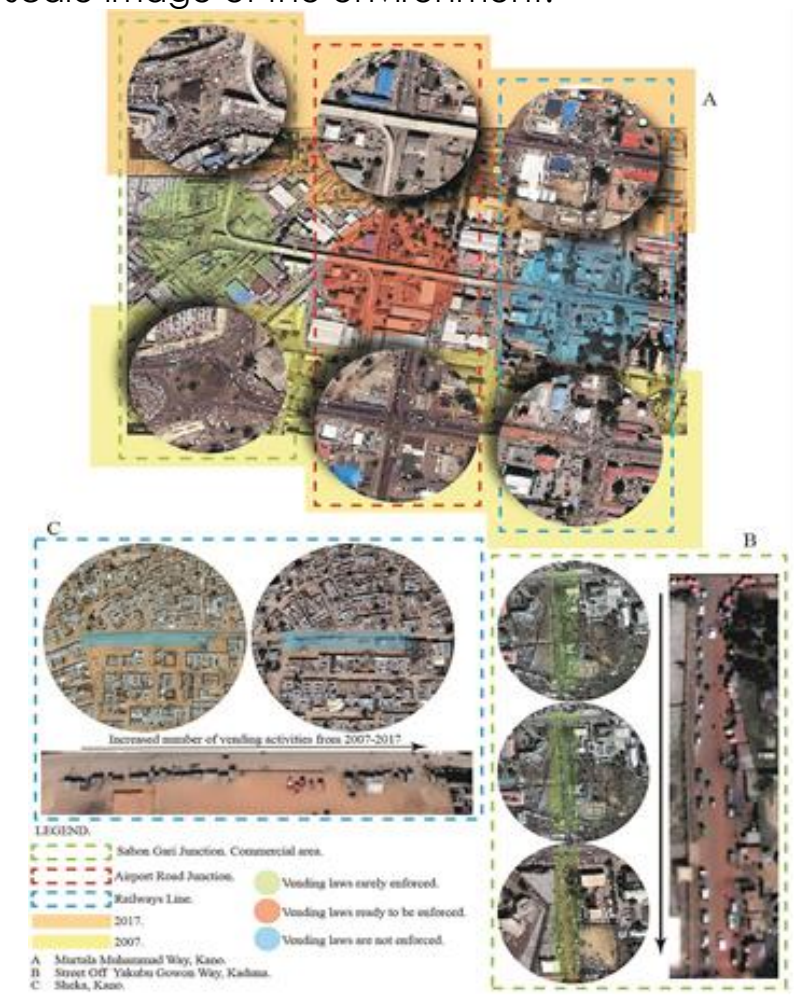

Figure 3: Spatial distribution of vendors in different urban centres. It shows areas that are hostile to vending activities and those that are not. Within A, it can be seen that different configuration of the urban environment and accompanying land uses (commercial, institutional and derelict lands) influences the extent to which the law is applied.

Source: Authors, 2018.

Others have proved less successful. The lack of sociological knowledge of street vending in Lagos has proved costly in governments programs. Olawoyin (2017a: 2017b) has shown the new phenomenon of ghost malls been set up, with specialised areas for vending activities. However, these malls have proved unfeasible to vendors whose customers are opportunistic buyers and are at the street levels. While still owing stalls within the malls, vendors have abounded them and return to the street sides. The schemes were exposed as not intended for the success of the vending activities but rather are political props to be waved as completed projects for electoral gains. The ghost-malls typology is simply for taking vendors of the street.

\subsection{Diversification of the economy in Nigeria.}

Diversifications are understood in Nigerian phraseology as the recalibration of the economy by reducing its dependency on crude oil earnings and allowing much revenue flow from previously neglected sectors. Nigeria's economy has been oil dependent since its commercialisation in the 1970s. Crude makes-up 10 per cent of GDP (NBS, 2018) yet accounts for up to 90 per cent of the nation's income while 
the sector employs less than $1 / 2$ a per cent of the countries workforce. The decline of global oil prices from $\$ 150$ to about $\$ 70$ today (29th March 2018) has questioned the sustainability of the state as an entity, resulting in a rapid response by the government to find an alternative way of financing expenditure. Other means of funding government's budget have to be planned.

Increasing the tax base, which currently stands at 7.8 per cent of the tax to GDP ratio (Oyedele, 2018), investing in the value chain around agriculture to increase productivity and expanding the mineral based mining activities have all be highlighted as areas for potential growth of the economy. Indeed, the Anchor Borrower Programme with more than 225,000 beneficiaries, has shown initial success by increasing local productivity and reducing imports "by almost 50 per cent to 280,000 tonnes in 2016" (Ogunmade et al., 2017). While those numbers are good - and with progress in other sectors - it is worth noting that farming, mining and industrial expansion can only go so far. With the population of Nigeria set to exceed 400 million by 2050 and majority living in cities, land competition will exacerbate, adding strain to already scarce resources. Likewise, manufacturing industries require long-term investment in equipment and physical infrastructure before their cushion effect could be felt within the economy.

Increasingly robotics, automation and ICT technologies are being deployed as substitutes (and complementary) in organisations and industries to reduce human errors and costs. As Nigeria moves from lower-middle income country to middle and high-income country, wages will rise to leave the industries and foreign capital to move elsewhere in search of cheaper labour. These scenarios put a hole to diversification claims concentrated in those sectors in the Economic Recovery and Growth Plan (ERGP), National Economic Empowerment and Development Strategy (NEEDS) program, and others alike. Neglecting the importance of vending activities as a dimension of the informal sector worth engaging and diversifying into could prove as an opportunity missed. The informal sectors as a whole employs majority of the people and represents 57-77 percent of the country's GDP (Ogbaubor \& Malaolu, 2013) and with little difference existing between formal and informal sector (Simone, 2004), exploring it as an economic opportunity for employment and increased tax based in the diversification exercise is prudent.

\section{Diversifying into street vending: what it would take.}

We argue as follows; to effectively have street vending shed its negative connotations and make a significant contribution to the overall image of any given city and in particular cities in Nigeria, there needs to be a holistic rethink of vending's contribution to the urban landscape and economy. This rethink will guide legislative action to decriminalize vending and bring about careful experimentations in urban planning and design. As the discourse of diversification and its implementation within the Nigerian context is still at its infancy, our paper casts a wide net into the possible avenues that can be leveraged to effectively uplift and upgrade the physical and the aesthetic aspects of vending activities without its viability as a commercial enterprise impaired. To this effect, we propose three dimensions of support namely; passive, active and tacit support.

\subsection{Passive Support}

Passive supports are categorized as non-material supports that are not directly involved in the shaping of a particular place or group of places. Policy and legal frameworks fall squarely under this category. Laws generally do not deal with the specificity of issues rather they deal with the overall context of the given programme. Hence, the malleability of the law is its general characteristics. In any given situation, a single provision within a legal code can be argued for one reason or another.

When it comes to vending, there seems to be a consensus amongst the planning elites that doesn't reflect the law as a flux. This has led to incessant demolition, confiscations and heavy fines on vending actors in Nigeria. Hence the call for a passive action.

What this represents in principle is the relaxation of hostile laws against vendors which has a success rate in evictions of 20 per cent, represented in multifaceted ways such as "government decisions" and grandiose "planning schemes" (Onodugo et al., 2016). Layouts and road expansion schemes are the usual culprits that instigate these hostilities. Hence, laws that protect vendors could be initiated and proposed with consultation and about street vendors.

Such law could be classified in different ways. An example could be; laws by goods type and geographical spread; goods that do not endanger public health and are safe for the environment. This would provide legitimacy to street vendors selling provisional goods, daily household items, books and electrical gadgets amongst others. 
Laws by geographical spread will deal with the extent with which vending is allowed within a location. Looking at the concentrated areas where vending activities are concentrated (markets, junction and public spaces), any city could decide - to a carefully determined radius the extent to which vending is allowed to different centre points. For example, from any market location, a distance of $500 \mathrm{~m}$ could be allowed as legal vending areas. This would allow for kart and table owners to establish a space for their activities without constant fear of harassment from the task force. It will also provide avenues for gradual upgrades of stalls, possibly to the level of the designed container.

\subsection{Active support}

If passive support does not directly effect change on the ground, then active support is meant to accomplish that exactly. This realm of supports deals with contributions from the design community, academia, NGOs, legal advocates. Support for the vendors has been few and far between. Aside from their organisations, which are often small and uncoordinated, little specialised organised support is offered. Many NGOs do facilitate the causes of informal communities at large. Justice and Empowerment Initiatives (JEI) and Isa Wali Empowerment Initiative offer crucial services by organizing legal practitioners, linking them to communities and helping other organisations

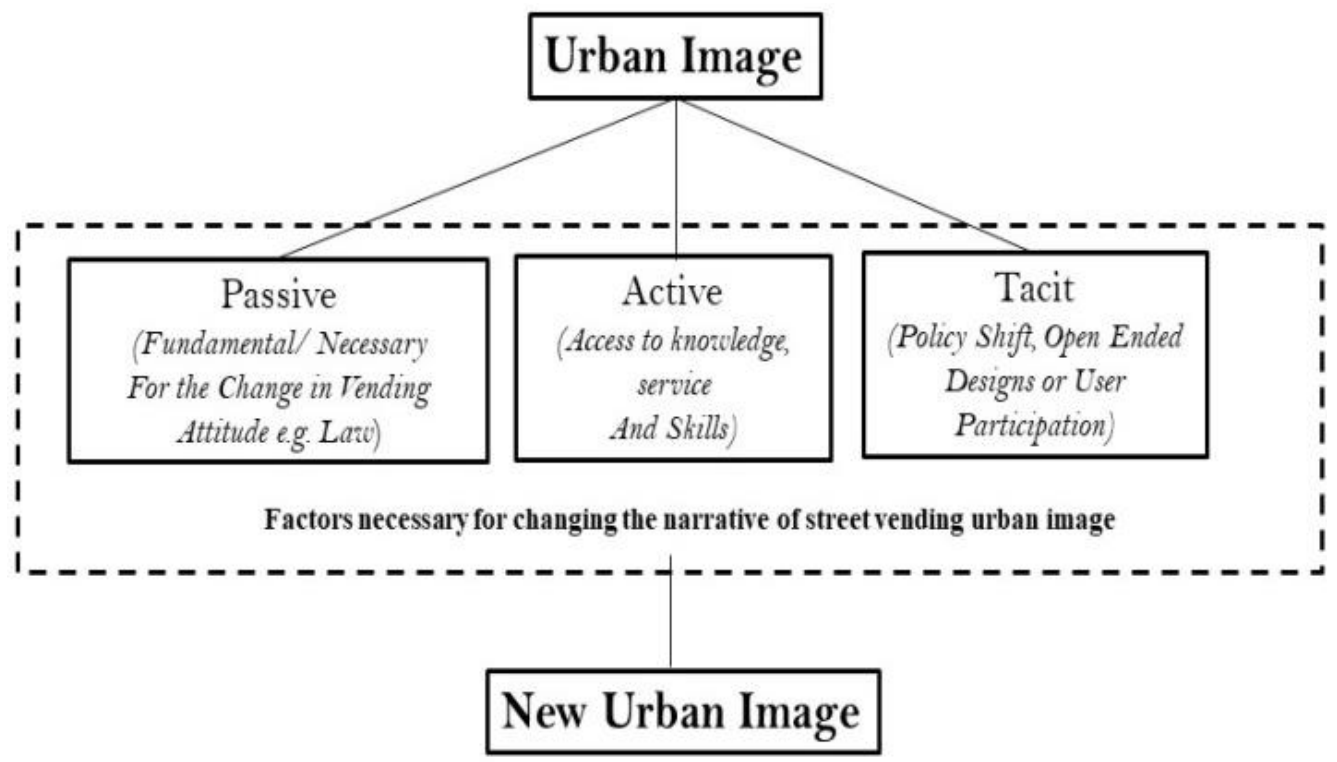

Figure 4: Proposed model for changing the narrative about street vending.

Diversifying into street vending could also be exploited for maintaining security. As Jacobs (1961) noted, security at the neighbourhood level is maintained through an unorganised complex network of individuals keeping their "eyes on the street." Mostly in her analysis, the contributions of shop owners feature centrally. They maintain relationships and are in constant lookout for unfavourable street behaviour, acting as "mayors" (Whyte, 1980), i.e. with keen interest regarding the social sustainability of the place. Street vendors acting as mayors can aid secure our neighbourhood parks, open spaces and darkened street allies, complimenting security forces in keeping the peace. Residents and regular visitors of the ancient cities within Nigeria feel this communal effect of eyes on the street. Legal freedom and clarity will, therefore, allow vendors to invest in their business rather than simply deciding between protecting their goods. with expertise and resources (JEl, 2018: IWEI, 2018). Though such services are needed, the peculiar nature of street vending demands single initiative advocacy or at the very least specialised units with such organisations with prior experience. Linking up with global networks such as Women in Informal Employment: Globalizing and Organizing (WIEGO) can benefit local vendors in areas of fighting draconian land and labour laws; acts and lobby groups to negotiate taxes and lobby allocations to the informal sector.

Active support regarding image shaping is not limited to the legal realm. Design knowledge will prove crucial to street vending activities not only in creating a signature style but also solving mobility and space management problems. Relationship with the academia can provide this interminable access to skill and knowledge. Through contact with students and professors, a plethora of designs and studies could be initiated to the benefits of vending communities at no cost. Knowledge produced could help 
guide the rehabilitation of dilapidated areas; the design of new vending areas; and provide individual/group design for stalls, tables, sheds, karts and carriers to interested vendors.

Having established the uneven distribution of vending activities as part of the perception of its undesirability (Bromley, 2000), key infrastructural provisions as well could boost this image misnomer. Provision of lighting and well-paved areas across different parts of the city decongests incessant vending in a single area. These single areas are where few services are provided, such as street lights, pavements and gutters long main roads, major junctions and public spaces. Increase provisions of these facilities not only disperse activities but also increase their operating hours into the night, resulting in an increased turnover and profits margins. This will also reduce noise and air pollution from to the use of generators.

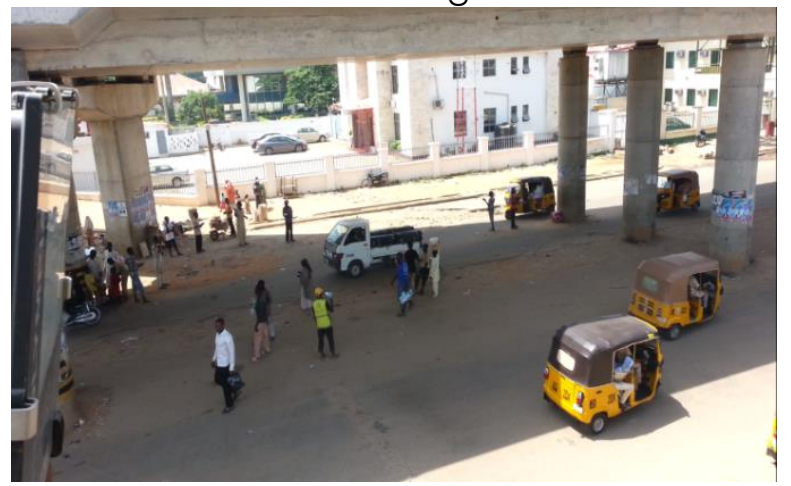

Figure 5: Street vendors on precarious location (at Airport road junction, Kano). They boarder banks and telecommunication companies, therefore, all mobile, carrying their merchandise. The high presence of police officers here leading to regular enforcement of the law. Hence, little investment in equipment on the vendor's part. This particular stretch along the road does not lend itself to permanent vending activities. Source: Authors (2017).

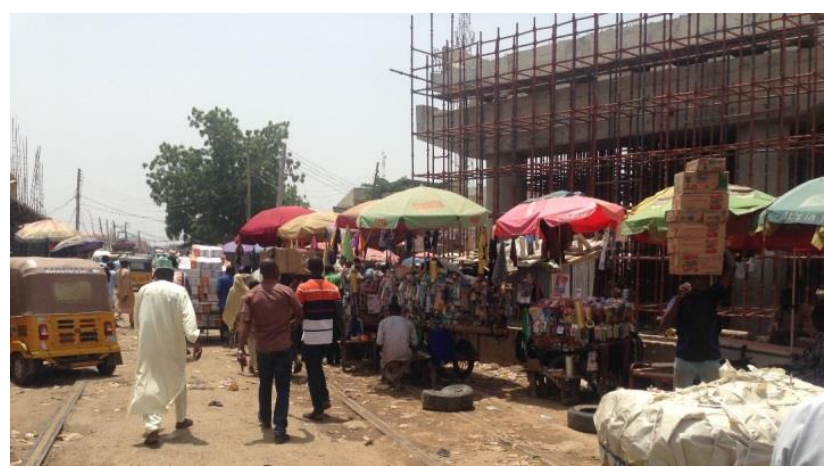

Figure 6: Mobile vendors on derelict lands that allows for temporal but steady informal activity. Vendors can invest in karts with umbrellas. Due to the constant ability to trade, vendors have a slightly higher amount of merchandise to trade and can continue to make improvements to their vending devices. Source: Authors (2017).

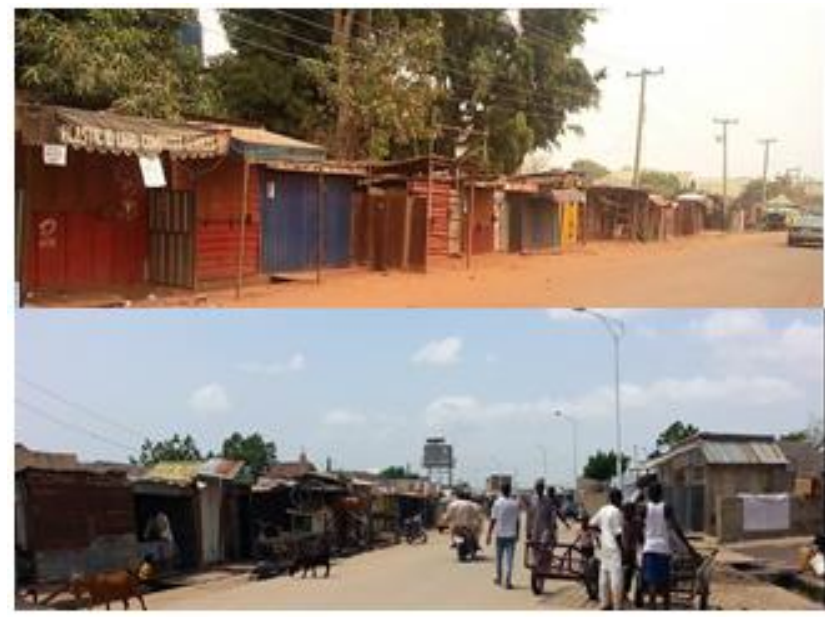

Figure 7\& 8: These are areas with tacit approval for vending activities. Different stall typologies exist at different stages of development, despite been at different locations. 6 providing different computing services and accessories is located at the CBD in Kaduna, off Yakubu Gowon Way, while 7, selling food and other perishable goods, is at the outskirts of Sheka district. Source: Authors (2017)

Decriminalizing street vending and diversifying into it can unlock its multifaceted potential that could reduce its perceived image problem. One dimension for this potential is ICT. Money transfer, market survey and weather forecast have been shown to improve farmer productivity around the world (Mittal \& Mehar, 2012). Cost of production has been brought down, barriers in accessing information cut and profit margins increasing just by deploying the telephone within the Nigerian farmer's community (Bolarinwa, \& Oyeyinka, 2011: Ogunniyi, \& Ojebuyi, 2016). Applications such as Verdant have begun to take hold of the industry. Technological savviness, therefore, has proven not to be a barrier when deployed in loweducated and low-income industries. Hence apps developed that will gather the planning and zoning ordinances regarding vending; provides real-time updates on a potential change in government policy and information about access to professional design and legal help can bring street vending closer to the general public. Seeing it in a new light of embracing modern technology and associating with centres of knowledge production can change the perception and narrative about it image problem within the city.

We have deliberately left the most contentious of active support for the last, monetary and material support. Issues of financial supports always hinge on complete integration into the formal economy. Though integration on paper seems appropriate, without safeguards, the less powerful will always seem to lose either land, capital or other resources to the most powerful (Roy, 2005). Hence, if credit lines are to be provided to a street vendor who owns a kiosk, patch of land or vehicle, careful consideration 
needs to be made to the ownership structure. This is to guard against the violent consumption of the venture capitalist, banks and loan sharks, and safeguard the property of vendors. Hence, land, kiosks and other assets should be held in cooperatives completely owned by an association of vendors. In the case of loan defaults by a particular vendor, the organization's bail/buys them out. This regulates assets from excessive speculations and limits the circle of decision making and control to the vendors. In this manner, cooperative accounts could be set up, loans taken from banks and investment made on a communal basis, often leading in the direction which serves the best interest of a group of vendors. Physical upgrades within this setup could be made easily and collectively, harmonising and change the image of the place.

\subsection{Tacit support.}

Tacit support involves deliberate attempt within the design and legal paradigm to make a vague proposal within specific geographical areas that allow for the possibility of co-creation of the urban built environment between street vendors and the planning authorities. This will form a morphological pattern that harnesses the logic and practicality of the organic pattern at the same time the gaining from the problem-solving rationale of the conventional planning.

This is to allow for the incorporation of already developing communities mostly at the peripheries, acting as a new paradigm for planning. The settlement could start as organic and then followed by periodical intervention from the authorities with as little disturbance as possible to the built-up area. The process could be vice versa, having a designed plan of main services, such as roads, sewage, schools and other social amenities. This then allows for infill by organic development including street vending activities. Such experimentation will give credence to the organic social process of vending, producing a hybrid image of old and new ushering a new way envisaging the urban environment.

\section{Conclusion}

There have been attempts at engaging with the informal communities in general and trying to incorporate them into the formal landscape of urban planning. Gouverneur (2014) proposes an "Informal Armature" (IA) approach that sees informal urbanizations as a dominant form of urban shaping. IA is meant as a guide rather than control of the future evolution of cities. Key to the
IA concepts are receptors, "areas made available for the settlers to self-construct their dwellings" and transformers which "are dynamic, rapidly changing zones for the provision of services, commerce, and production, and eventually more complex urban uses and real-estate operations".

Our tacit support borrows from Gouverneur perspective. Spaces, where vendors occupy, are mostly public such as street, sidewalks and urban parks. In the case of parks, rather than conceptually separating receptors from transformers spatially, we argue that a temporal (time-based) understanding will aid in changing the urban image narrative of street vendors. Vendors set up stalls in urban spaces (receptors first), and before reaching a critical mass, necessary urban infrastructure are provided together with plans and proposal recommending complimentary/necessary activities within such park and spaces that suit the immediate local population. Such kind of initiatives gains from the organic prowess of the informal sector and the medium and short-term strategies of the planning regime.

The desire for economic capital and political elites to forge a new material culture that absorbs street vending activities fail to appreciate the importance of flux and tensions that exist within cities. Planners, administrators and investors need to understand that cities are an agglomeration of its parts which give rise to its overall character. Transcending the 'place-city problem,' i.e. a better understanding of the whole rather than looking at the city in cells/blocks (Hillier, 1996), actors shaping the urban environment will appreciate the need for diversity in the urban image. Imageability is crucial in navigating through a city (Kubat et al., 2012: Lynch, 1960) and understanding its identity (Relph, 2007 [1976]).

Diversification of the economy in Nigeria has potential not only to include the urban poor within the planning framework, boost their economic activity but also deepening social integration within the city. Changing the narrative from a negative tone to a discourse of inclusion and a credible alternative should be among the first steps in that process. The proposals made here to that effect do not constitute an exhaustive list of recommendations rather a starting point for discussions with students of planning, design and others concerned with the physical environment. Carefully exploiting these means that gradually shape the informal sector by improving its physical, economic and environmental conditions can create and shape a new image within the city palatable to all parties involved in 
the struggle.

We have shown that street given the right conditions and incentives, street vendors make appropriate improvements to their stalls. This gradual upgrading's from handheld merchandising to the use of karts, then fixed shops/kiosk varying in construction material shows a desire for creating a suitable environment for business. However, this only comes when there is lack of hostilities from the authorities, and it makes financial sense to the vendors. Our framework is an attempt make such revisions by the vendor possible. Diversification of the economy has the potential to push these changes in the physical environment and potentially to the vendor's immediate vicinity.

Our recommendations have transverse the legal, political, business, academic and the civil society realms. The potency of each of these realms in changing the narratives on street vending and its image within the urban landscape needs further research for it to be established.

\section{Acknowledgements}

Authors extend their thanks to Aliyu Ado Shehu, Muhammad Mustapha and Muhammad Mubarak Balarabe for their support and contribution during our field study. This research did not receive any specific grant from funding agencies in the public, commercial, or not-forprofit sectors.

\section{Conflict of interests}

The authors declare no conflict of interest.

\section{References}

Ahmad, M. (2015). Kano marks 100 "illegal structures" for demolition-premium times in Nigeria. Retrieved November 11, 2016, from North

West.

http://www.premiumtimesng.com/regional/n west/188679-kano-marks-100-illegalstructures-for-demolition.html

Alabelewe, A. (2018). Beggars protest against ElRufai's anti-begging, hawking law. The Nation Nigeria. Retrieved, 29.

http://thenationonlineng.net/beggarsprotest-el-rufais-anti-begging-hawking-law/

Appadurai, A. (2001). Deep democracy: urban governmentality and the horizon of politics. Environment and urbanization, 13(2), 23-43. doi/pdf/10.1177/095624780101300203

Binniyat, L. (2018). Buy from street hawkers and be jailed-Kaduna govt. https://www.vanguardngr.com/2016/05/buystreet-hawkers-go-jailed-kaduna-govt/
Bolarinwa, K. K., \& Oyeyinka, R. A. (2011). Use of cell phone by farmers and its implication on farmers' production capacity in Oyo State Nigeria. education, 16, 13-3. https://pdfs.semanticscholar.org/fe6a/1318c 67cb9bd5cb58f604fc45a95e15260b8.pdf

Brenner, N., \& Schmid, C. (2011). Planetary urbanisation. In M. Gandy (Ed.), Urban Constellations (pp. doi/pdf/10.1177/1367549413497696 10-13)

Brenner, N. (2013). Theses on urbanization. Public culture, 25(1 (69)), 85-114. https://static l.squarespace.com/static/53a0 503be4b0a429a2614e8b/t/53ffc5eee4b0c33 14cbc21e1/1409271278878/Brenner.pdf

Bromley, R. (2000). Street vending and public policy: a global review. International Journal of Sociology and Social Policy, 20(1/2), 1-28. https://doi.org/10.1108/01443330010789052

Alliance, C. (2011). Demolition of businesses leaves many Kano shopkeepers destitute. Retrieved November 11, 2016. https://www.researchgate.net/publication/2 83507933 Governance_and_Security_in_Ana mbra State

Cohre, S. (2008). The Myth of the Abuja Master Plan: Forced Evictions Urban Planning in Abuja, Nigeria. Geneva, Switzerland: Centre for Housing Right and Evictions. https://curve.coventry.ac.uk/open/file/286e2 64c-3d26-4448-80496f2ef3fda727/1/chimacomb.pdf

Crossa, V. (2013). Play for protest, protest for play: Artisan and vendors' resistance to displacement in Mexico City. Antipode, 45(4), 826-843.

https://s3.amazonaws.com/academia.edu.d ocuments/37401223/Crossa_A_13.pdf?

disposition=inline\%3B\%20filename\%3DPlay_for _Protest_Protest_for_Play_Artisa.pdf

Hillier, B. (1997). Cities as Movement Economies. In Intelligent environments (pp. 295-344). https://www.researchgate.net/publication/3 2885939 Cities as Movement_Economies

IWEI. (2018). Iwei-ng.org. Retrieved 27 March 2018, from http://iwei-ng.org/

Jane, J. (1961). The death and life of great American cities. New-York, NY: Vintage. https://en.wikipedia.org/wiki/The Death_and Life_of_Great_American_Cities

JEl. (2018). Justice \& Empowerment Initiatives. Retrieved 27 March 2018, from http://www.justempower.org/

Kazeem, Y. (2017). Lagos wants to be a modern mega city, so it's forcing thousands of slum dwellers from their homes. Quartz. Retrieved 24 March 2017, from https://az.com/936761//agos-wants-to-be-a- 
modern-mega-city-so-its-forcing-thousandsof-slum-dwellers-from-their-homes/

Kubat, A. S., Özbil, A., Özer, Ö., \& Ekinoğlu, $H$. (2012, January). The effect of built space on wayfinding in urban environments: a study of the historical peninsula in Istanbul. In Eighth International Space Syntax Symposium (Vol. 8029).

https://s3.amazonaws.com/academia.edu.d ocuments $/ 32258908 /$ the effect_of built_spa ce on wayfinding in urban environments.p df?

Lynch, K. (1960). The image of the city (Vol. 11). Cambridge, MA: MIT Press. http://www.miguelangelmartinez.net/IMG/p $\mathrm{df} / 1960$ Kevin Lynch The Image of The Cit y_book.pdf

NBS. (2018). Nigerianstat.gov.ng. Retrieved 29 March 2018, from http://nigerianstat.gov.ng/

Mittal, S., \& Mehar, M. (2012). How mobile phones contribute to growth of small farmers? Evidence from India. Quarterly Journal of International Agriculture, 51(3), 227. https://ageconsearch.umn.edu/bitstream/15 5478/2/2 Mittal.pdf

Ogunniyi, M. D., \& Ojebuyi, B. R. (2016). Mobile phone use for agribusiness by farmers in Southwest Nigeria. Journal of Agricultural Extension, 20(2), 172-187. file:///C:/Users/CIU/Downloads/149367392990-1-SM\%20(1).pdf

Ogbuabor, J. E., \& Malaolu, V. A. (2013). Size and causes of the informal sector of the Nigerian economy: Evidence from error correction mimic model. Journal of Economics and Sustainable Development, 4(1), 85-103. https://s3.amazonaws.com/academia.edu.d ocuments/30633219/Size_and_Causes_of th e_Informal Sector_of the Nigerian_Economy .pdf?

Ogunmade, O., Ajimotokan, O., \& Okoh, G. (2017, May 17). Ogbeh: Nigeria's Rice Policy Hurting Thai Production. Retrieved March 29, 2018,

from

https://www.thisdaylive.com/index.php/2017 105/17/ogbeh-nigerias-rice-policy-hurtingthai-production/

Ortiz, C. (2011). Negotiating downtown renewal in Colombia: is the right to the city a public discourse or a grounded citizenship practice?. In The struggle to belong Dealing with diversity in 21 st-century urban settings. (p. unpaged). Amsterdam. Retrieved from http://www.rc21.org/conferences/amsterda m2011/edocs/Session\%2018/18-1-Ortiz.pdf

Onodugo, V. A., Ezeadichie, N. H., Onwuneme, C. A., \& Anosike, A. E. (2016). The dilemma of managing the challenges of street vending in public spaces: The case of Enugu City,
Nigeria. Cities, 59, 95-101. https://doi.org/10.1016/j.cities.2016.06.001

Oyedele, T. (2018). Economic and fiscal implications of Nigeria's rebased GDP. PWC. Retrieved 29 March 2018, from https://www.pwc.com/ng/en/publications/g ross-domestic-product-does-size-reallymatter.html

Shane, D. G. (2011). Urban design since 1945: a global perspective (p. 360). Chichester: Wiley. https://h20zvcx7nd 11 .storage.googleapis.co m/EirFQNnxi8nQAaSFhil 1.pdf

Simon, P. B. (1998). Informal responses to crises of urban employment: an investigation into the structure and relevance of small-scale informal retailing in Kaduna, Nigeria. Regional Studies, 32(6), 547-557. https://doi.org/10.1080/00343409850119111

Simone, A. (2004). For the city yet to come: Changing African life in four cities. Duke University

Press. https://books.google.com.cy/books?

on the history of an idea, 21-78. https://books.google.com.cy/books?

Sunday, E., Ebiri, K., Akpan, A., \& Akhaine, S. (2018). Street hawkers: How they fare in Lagos, Port Harcourt, Calabar and Kaduna. Retrieved 29 March 2018, from https://guardian.ng/sundaymagazine/street-hawkers-how-they-fare-inlagos-port-harcourt-calabar-and-kaduna/

31 Swanson, K. (2007). Revanchist urbanism heads south: the regulation of indigenous beggars and street vendors in Ecuador. Antipode, 39(4), 708-728. https://doi.org/10.1111/j.14678330.2007.00548.x

Roy, A. (2005). Urban informality: toward an epistemology of planning. Journal of the american planning association, 71(2), 147158.

https://www.tandfonline.com/doi/pdf/10.108 0/01944360508976689

Relph, E. (2007). On the identity of places [1976]. In M. Carmona \& S. Tiesdell (Eds.), Urban Design Reader. Pp. 103-107, Oxford: Architectural Press. https://ecommons.cornell.edu/bitstream/ha ndle/1813/34149/ak383.pdf? sequence=1

Whyte, W. H. (1980). The Social Life of Small Urban Spaces (Conservation Foundation, Washington, DC) Google Scholar. https://trid.trb.org/view/521122

Yatmo, Y. A. (2008). Street vendors as 'out of place'urban elements. Journal of Urban Design, 13(3), 387-402. https://www.tandfonline.com/doi/full/10.108 $\underline{0 / 13574800802320889}$ 